Int. Archs Allergy appl. Immun. 1985;78:I-V

\title{
Contents, Vol. 78, 1985
}

Vol. 78, 1985

\section{Editors-in-Chief}

L.Å. Hanson, Göteborg P. Kallós, Helsingborg F. Milgrom, Buffalo, N.Y. R.A. Reisfeld, La Jolla, Calif. K. Rother, Heidelberg Z. Trnka, Basel G.B. West, Epsom

Founded 1950 by D. Hariey, P. Kallós, W. Löffler and F.W. Wittich Continued by E.A. Brown (1952-1954), W. Kaufman (1955-1967),

F. Hahn (1961-1972), H.C. Goodman (1963-1975) and R.R.A. Coombs (1955-1984)

Contributing Editors

C.J. Abeyounis, Buffalo, N.Y, M. Miyasaka, Basel N.F. Adkinson, Jr., Baltimore, Md. W.

Müller-Ruchholtz, Kiel St. Ahlstedt, Uppsala F. Ørskov, Copenhagen B. Albini, Buffalo, N.Y.

Ö. Ouchterlony, Göteborg

G. Andres, Buffalo, N.Y. Z. Ovary, New York, N.Y.E.L. Becker, Farmington, Conn. P.

Perlmann, StockholmW.E. Brocklehurst, Windlesham E. Pick, Tel Aviv

A. Capron, Lille M. Plaut, Baltimore, Md.

A. Cerletti, Basel R.E. Reisman, Buffalo, N.Y.C.G. Cochrane, La Jolla, Calif. G.

Riethmüller, München

B. Diamant, Copenhagen M. Roitt, London

P. Dukor, Basel U. Rother, Heidelberg

L. Edebo, Göteborg G. Sandberg, Stockholm

S. Elsayed, Bergen H.D. Schlumberger, Wuppertal

W.P. Faulk, Nice K.H. Schulz, Hamburg

P.G.H. Gell, Birmingham A. Sehon, Winnipeg

I. Glazer, Tel Aviv O. Strannegård, Göteborg

R.A. Good, St. Petersburg, Fla. A. Szentivanyi, Tampa, Fla.

M. Hess, Bern O. Tender, Bergen

L. Hudson, Beckenham G. Torrigiani, Geneve

H. Isliker, Lausanne J.L. Turk, London

S.G.O. Johansson, Stockholm E.R. Unanue, Boston, Mass.

E.A. Kabat, New York, N.Y. B.H. Waksman, New York, N.Y.

K. Kano, Tokyo G. Wick, Innsbruck

\section{DBffi}

S. Karger Medical and Scientific Publishers · Basel · München · Paris — London · New York · New Delhi $\cdot$ Singapore $\cdot$ Tokyo $\cdot$ Sydney

Drug Dosage

The authors and the publisher have exerted every effort to ensure that drug selection and dosage set forth in this text are in accord with current recommendations and practice at the time of 
publication. However, in view of ongoing research, changes in government regulations, and the constant flow of information relating to drug therapy and drug reactions, the reader is urged to check the package insert for each drug for any change in indications and dosage and for added warnings and precautions. This is particularly important when the recommended agent is a new and/or infrequently employed drug.

All rights reserved.

No part of this publication may be translated into other languages, reproduced or utilized in any form or by any means, electronic or mechanical, including photocopying, recording,

microcopying, or by any information storage and retrieval system, without permission in writing from the publisher or, in the case of photocopying, direct payment of a specified fee to the Copyright Clearance Center (see 'Information for Readers and Subscribers').

(C) Copyright 1985 by S. Karger AG, P.O. Box, CH-4009 Basel (Switzerland) Printed in

Switzerland by Buchdruckerei Basler-Zeitung AG, Basel

Contents Vol. 78,1985

No. 1

Original Paper

A Monoclonal Antibody-Based Radioimmunoassay for the in vitro Production of IgE by

Lymphocyte Cultures Zaunders, J.J.; Ziegler, J.B.; Penny, R.; Cooper, D.A. ... 1

Prevention of Anaphylactoid Reactions after RadiographicContrast Media Infusion by Combined Histamine Hi- and\%oReceptor Antagonists: Results of a Prospective Controlled TrialRing, J.;

Rothenberger, K.-H.; Clauss, W 9

Identification of Orchard Grass (Dactylis giomerata) PollenAllergens following Electrophoretic

Transfer to NitrocelluloseFord, S.A.; Tovey, E.R.; Baldo, B.A

Lymphocyte Transformation Test in Drug-Induced Toxic Epidermal Necrolysis

Roujeau, J.-C; Albengres, E.; Moritz, S.; Piacentino, A.;Cuny, M.; Revuz, J.; Touraine, R 22

Leukocyte Membrane Receptors in Meningitis and Other Bacterial InfectionsNæss, A.;

Halstensen, A.I.; Solberg, CO 25

Detection of Soy Protein in Soy Lecithin, Margarine and, Occasionally, Soy Oil Porras, O.;

Carlsson, B.; Fällstròm, S.P.; Hanson, L.Å. . . 30

Immunoglobulin Production in Epstein-Barr Virus-Transformed Lymphoblastoid Cell Lines in

Patients with Ataxia Telangiectasia Ariga, T.; Sakiyama, Y.; Matsumoto, S.; Okano, M.; Osato,

T. 33

Studies on Alternaria Allergens. V. Comparative Biochemical and Immunological Studies of

Three Isolates of Alternaria tenuis Cultured on Synthetic Media

Vijay, H.M.; Young, N.M.; Jackson, G.E.D.; White, G.P.;Bernstein, I.L 37

Mechanism of the Action of Amoxanox (AA-673), an Orally Active Antiallergic Agent Saijo, T.;

Kuriki, H; Ashida, Y.; Makino, H.; Maki, Y. . 43

Effects of Anti- $\varepsilon$ on Total and Specific IgE Levels in Adult Mice Bozelka, B.E.; McCants, M.L.;

Salvaggio, J.E.; Lehrer, S.B. 51

Characterization of the IgG Antibody Response to TimothyGrass Pollen AntigensMalley, A.;

Hopkins, S.J.; Turner, K.J 57

In vivo Effects of Cyclosporin A: Abrogation of the Inductionof Experimental Allergic Orchitis

and Sparing of the Generation of Suppressor CellsHojo, K.; Hiramine, C 63

High-Performance Liquid Chromatography of Cladosporiumherbarum. Identification of

Allergens with ImmunologicalTechniquesLandmark, E.; Aukrust, L 
The Role of 5-Lipoxygenase Pathway Activation in BasophilHistamine ReleaseMorita, Y.; Suzuki, S.; Miyamoto, T 77

Isotopic Analysis of Antibody Response to a Food Antigen in Inflammatory Bowel Disease Paganelli, R.; Pallone, F.; Montano, S.; Le Moli, S.; Matri-cardi, P.M.; Fais, S.; Paoluzi, P.; D'Amelio, R.; Aiuti, F. . 81

Goblet Cell Number in the Nasal Mucosa Relates to Cell-Mediated Immunity in Patients with Antibody Deficiency Syndromes (with 1 color plate)

Karlsson, G.; Hansson, H.-A.; Petruson, B.; Björkander, J.;Hanson, L.A 86

Pharmacologic Modulation of the IgE or Ca2+ IonophoreA23187 Mediated Ca2+ Influx, Phospholipase Activation, and Histamine Release in Rat Basophilic Leukemia CellsUrata, C; Siraganian, R.P 92

C56 Formation in the Reaction Mixture of Isolated Complement Components through the Classical Complement PathwayKitamura, H.; Tsuboi, M.; Nagaki, K 101

Short Communication

Uptake of Intravenously Administered Soluble Immune Complexes by Type I Alveolar Cells and Macrophages in Mice Kanayama, Y.; Amatsu, K.; Negoro, N.; Takeda, T.; Inoue, T. 108

Book Review 112

Books Received at the Editorial Office $\quad 112$

No. 2

Original Paper

Pharmacological Characterization of Mouse Ear PCA

Inagaki, N.; Goto, S.; Nagai, H.; Koda, A 113

Modulatory Effects of Freund's Adjuvant Treatment on Mast Cell Histamine Release and

Homocytotropic Antibody Synthesis Bergstrand, H.; Andersson, I.; Pauwels, R.; Bazin, H. . . . 118

Neutrophil and Monocyte Adherence in Diabetes mellitus, Alcoholic Cirrhosis, Uraemia and Elderly PatientsKelly, M.K.; Brown, J.M.; Thong, Y.H 132

IV

Contents

Characterization of Allergens and Patient Sera by a Nitrocellulose Immunoprint

TechniqueBengtsson, A.; Rolfsen, W.; Einarsson, R 139

Early Rheumatoid-Like Synovial Lesions in Rabbits Drinking Cow's Milk. I. Joint Pathology

Welsh, C.J.R.; Hanglow, A.C.; Conn, P.; Barker, T.H.W.;Coombs, R.R.A 145

Early Rheumatoid-Like Synovial Lesions in Rabbits Drinking Cow's Milk. II. Antibody

Responses to Bovine Serum Proteins Hanglow, A.C.; Welsh, C.J.R.; Conn, P.; Coombs, R.R.A. 152

Effects of Pneumococcal Vaccination on Tonsillo-Pharyngitis and Upper Respiratory Tract Flora Christensen, P.; Hovelius, B.; Prellner, K.; Rosen, C; Chris-tensen, K.K.; Kurl, D.N.; Larsson, L.; Stjernquist-Desatnik, A.;Schalén, C 161

Detection of a Thermostable Brain Antigen in the Circulationof Patients after Cerebrovascular AccidentChen, H.; Soria, E.; Milgrom, F 167

Antibody Determination against Aspergillus fumigatus by Means of the Enzyme-Linked Immunosorbent Assay. II. Physico- and Immunochemical Properties of the Polystyrene-Binding Components 
Kauffman, H.F.; Heyden, P.J. van der; Laan, S. van der;Heide, S. van der; Beaumont, F.; Vries, K. de 174

Analytic Study of the Differential Anticomplementary Effects of Dextran Sulphate and Heparin in the Assay for the Mouse Alternative Pathway

Klerx, J.P.A.M.; Van Dijk, H.; Van der Maaden, W.J.;Willers, J.M.N 182

Hyperventilation-Induced Bronchoconstriction in GuineaPigsChapman, R.W.; Danko, G 190

Glycoprotein Allergens in Pollen of Timothy. I. Investigationof Carbohydrates Extracted from

Pollen of Timothy(Phíeum pratense) and Purification of a Carbohydrate-Containing Allergen by

Affinity Chromatography on Concanav-alin A-SepharoseHaavik, S.; Smestad Paulsen, B.S.;

Wold, J.K 197

Allergens in Pollen from Mugwort (Artemisia vulgaris L.). I.Partial Characterization of Allergen

Preparations fromMugwort Pollen with Emphasis on the CarbohydrateMoietySmestad Paulsen,

B.; Flø, L.; Nesje, G.; Wold, J.K 206

Dextran and Antidextran Antibodies in the Sera of Patients with Liver Diseases

Morito, T.; Nishimaki, T.; Saito, K.; Yoshida, H.; Kasukawa, R.; Kano, K 213

Short Communications

In vitro Natural Killer and Killer Cell Functions in Uremia

Langhoff, E.; Ladefoged, J 218

Thoughts on Mast Cells, Histamine Release and Immunoglob-ulin EWest, G.B

Book Reviews 224

News Item 224

No. 3

Original Paper

Effect of Seasonal Ragweed Exposure on Immunoglobulin E Antiragweed Antibodies in

Cultures of Peripheral Mononu-clear Cells, Plasma and Nasal Secretions Naclerio, R.M.; Plaut,

M.; Adkinson, N.F.; Norman, P.S., Jr. 225

Activities of a Soluble Extract from Lymphoid Cells of MRL Mice. Effect on B Cell

Differentiation in vitro Katagiri, T.; Nakano, T.; Ueno, K; Ohsugi, Y.; Fujiwara, M. 233

Effects of Various Cytochalasins on the IgE-Mediated Serotonin Release from Rat Basophilic

Leukemia Cells Teshima, R.; Ikebuchi, H.; Sekita, S.; Natori, S.; Terao, T. 237

Direct Interaction of Guinea Pig Eosinophils and AdrenergicAgentsMasuyama, K.; Ishikawa, T 243

Purification and Partial Characterization of the Allergen Ag-54 from Cladosporium herbarum

Swärd-Nordmo, M.; Wold, J.K.; Smestad Paulsen, B.;Aukrust, L 249

Binding and Activation of Human Precursor $\mathrm{Cl}$ by SolubleAggregates of Human and Rabbit

IgGDoekes, G.; van Seggelen-van Zijp, A.CM.; van Es, L.A.;Cats, A.; Daha, M.R256

Glycoprotein Allergens in Pollen of Timothy. II. Isolation andCharacterization of a Basic

Glycoprotein AllergenHaavik, S.; Smestad Paulsen, B.; Wold, J.K 260

Further Characterization Including Preliminary ChemicalAnalysis of Antigen MLW1 from

Mycobacierium lepraeReitan, L.J.; Closs, O.; Jantzen, E 269

Thymus Dependence of Connective Tissue Mast Cells: AQuantitative Cytofluorometric Study of the Growth of Peritoneal Mast Cells in Normal and Athymic RatsAldenborg, F.; Enerbäck, L 277

Purification and Characterization of a Major Allergen fromDactylis glomerata Pollen: The Ag

DglMecheri, S.; Peltre, G.; David, B 283 
Induction of a Passive Cutaneous Anaphylaxis Inhibitory Factor in MiceMecheri, S.; Peltre, G.; David, B 290

Grass Pollen Allergens: Antigenic Relationships Detected Using Monoclonal Antibodies and Dot Blotting ImmunoassaySingh, M.B.; Knox, R.B 300

Lymphocyte Subsets in Infants: Relationship to Feeding, Atopy, Atopic Heredity and InfectionsTainio, V.-M. $\quad 305$

Modulation of the Host-versus-Graft Reaction of the PoplitealLymph Node by Small Numbers of Dendritic Cells Injectedat a Distant SiteMertin, L.A.; Mertin, J 311

Regulation of Natural Killer Cell Activity and Interferon Production in the Rat Lung Following Aerosol ChallengeFarrell, H.E.; Holt, P.G.; Shellam, G.R 318

Short Communications

Induction of Class II MHC Antigens in Cultured EpithelialCells from Rat GutKilshaw, P.J 326

Karlsson/Hansson/Petruson/Björkander/Hanson

Plate I

$\backslash \neq$ 


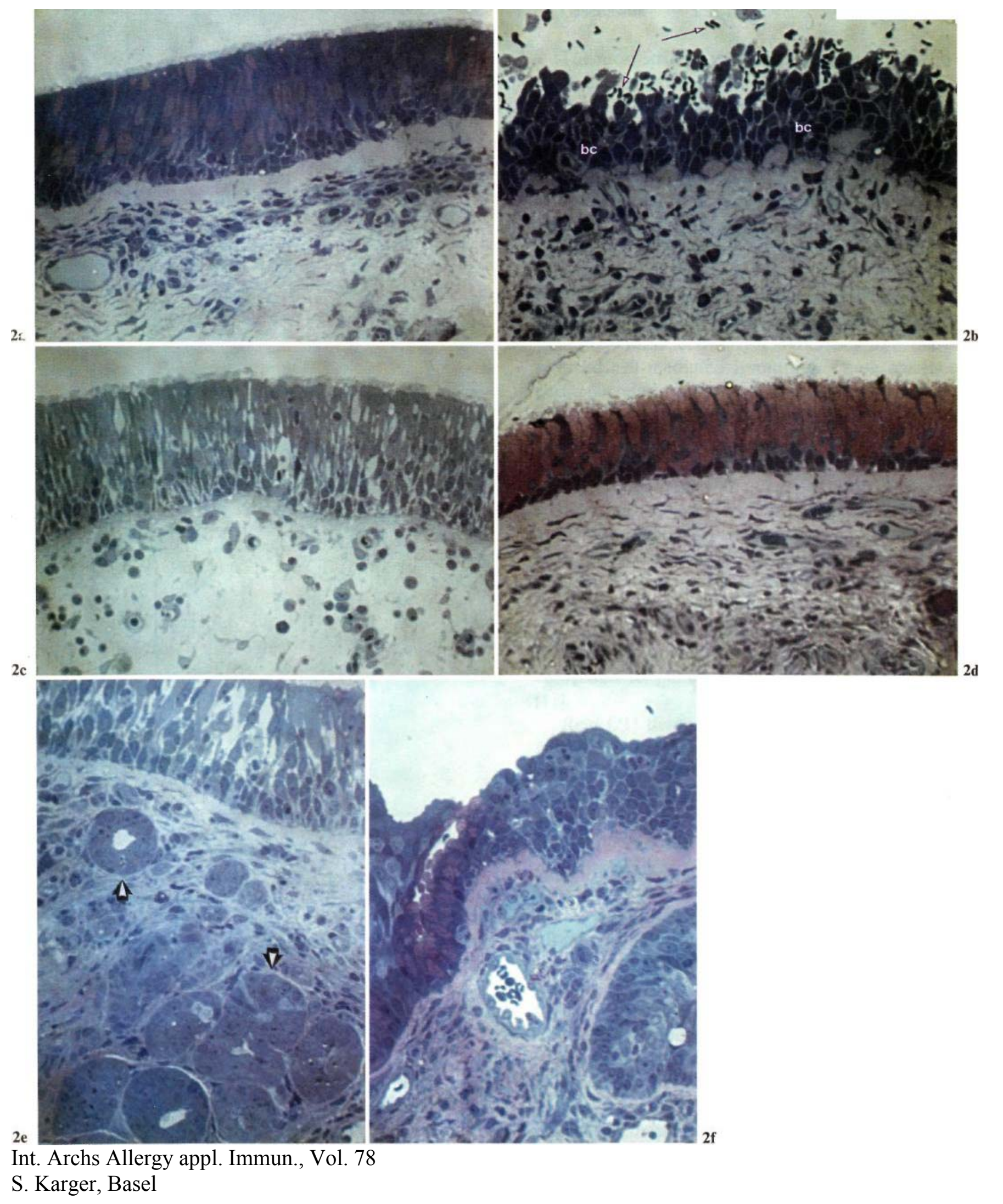


Contents

$\mathrm{V}$

Suppression of Allergic Reactivity by Intestinal Helminths:Susceptibility Is a Function of IgE Responder PhenotypeTurner, K.J.; Shannahan, K.; Holt, P.G 329

Lymphocyte Transformation Induced by Autologous Cells.XVII. Lower Autologous Mixed Lymphocyte Reaction inSubjects with a History of HayfeverBovbjerg, D.H.; Wang, V.A.;

Schwab, R.; Lebenger, K.S.;Siskind, G.W.; Weksler, M.E 332

Book Reviews $\quad 335$

No. 4

Original Paper

Investigation of the Allergenicity of $\beta$-Lactoglobulin and ItsCleavage FragmentsHuang, Q.;

Coleman, J.W.; Stanworth, D.R 337

Enhancement of Hydrophobic Interaction, Negative Chargeand Phagocytosis by Dinitrophenyl

Ligand Coupling to Salmonella typhimurium 395 MSEdebo, L.; Richardson, N 345

The Effects of Binding Mouse IgA to Dinitrophenylated Salmonella typhimurium on

Physicochemical Properties and Interaction with Phagocytic CellsEdebo, L.; Richardson, N.;

Feinstein, A 353

Fragments of IgE Antibodies in Human Feces

Kolmannskog, S.; Marhaug, G.; Haneberg, B 358

Nickel Binding and Uptake in Thymocytes and Peripheral BloodLymphocytes of Nickel-Allergic and Control SubjectsNordlind, K 364

Subclasses of Human IgG Anti-Fab Antibodies: Parameters forOptimum DetectionPersselin, J.E.; Keld, B.; Fried, L.; Stevens, R.H 368

Demonstration of Antibodies to Mosquito Antigens in Man by Immunodiffusion and ELISA

Ailus, K.; Palosuo, T.; Brummer-Korvenkontio, M.; Ran-tanen, T.; Reunala, T 375

Tumour-Induced Suppression of Delayed-Type Hypersensitiv-ity in the Mouse: Independence of Cyclophosphamide-Sen-sitive Suppressor Cells Mcîntosh, L.C.; Pugh-Humphreys, R.G.P.;

Thomson, A.W. 380

Immunologic Responses to Intravenous Streptokinase in Dogs Dykewicz, M.S.; McGrath, K.G.;

Harris, K.E.; Patterson, R. 386

Polyclonal B Cell Activators Inhibit Contact Sensitivity to

Oxazolone in Mice by Potentiating the Production of Anti-

Hapten Antibodies that Induce T Suppressor Lymphocytes

Acting through the Release of Soluble Factors

Campa, M.; De Libero, G.; Benedettini, G.; Mori, L.;

Angioni, M.R.; Marelli, P.; Falcone, G 391

Suppression of the Allergic Contact Reaction in the Guinea Pig

by Cyclosporin A

Anderson, C; Groth, 0396

Polyclonal Activation of Guinea Pig Spleen Lymphocytes

Neveu, P.J.; Perdoux, D 401

Release of Leukotriene C4 from Human Eosinophils and Its

Relation to the Cell Density

Kajita, T.; Yui, Y.; Mita, H.; Taniguchi, N.; Saito, H.;

Mishima, T.; Shida, T 406 
Comparison of Measurements of Serum Venom-Specific IgG by Radioimmunoassay and Enzyme Immunoassay

Wypych, J.I.; Abeyounis, C.J.; Reisman, R.E 411 Isolation of Schistosoma japonicum Egg-Derived Neutrophil Stimulating Factor: Its Role on Eosinophil Chemotactic Factor Release from Neutrophils Owhashi, M.; Horii, Y.; Ishii, A 415 Immunochemical Characterization of Antigens of Parietaria judaica Pollen. Identification of Allergens by Means of Crossed Radio Immunoelectrophoresis

Geraci, D.; Billesbølle, K.B.; Cocchiara, R.; Løwenstein, H.; Ipsen, $\mathrm{H} \quad 421$

Adhesion of Guinea Pig Polymorphonuclear Leukocytes to Autologous Aortic Strips: Influence of Chemotactic Factors and of Pharmacological Agents which Affect Arachidonic Acid Metabolism

Fricke, D.; Damerau, B.; Vogt, W 429

Aspirin-Sensitive Asthma: Abnormal Platelet Response to

Drugs Inducing Asthmatic Attacks. Diagnostic and Physio-pathological Implications Ameisen, J.C.; Capron, A.; Joseph, M.; Maclouf, J.; Vorng,

H.; Pancré, V.; Fournier, E.; Wallaert, B.; Tonnel, A.B. . 438

Short Communication

Antigenic Competition in IgE, IgGl and IgG2 Antibody Production in the MouseMacedo Soares, M.F.; Macedo, M.S. de; Mota, 1 449

News Item 452

Author Index 453E. Erratum 452

Author Index 453

International Archives

of Allergy and Applied

Immunology 